\title{
Selection of Injection Parameters for Various Engine Speeds in PCCl- Based Diesel Combustion with Multiple Injection
}

\section{$\operatorname{AUTHOR}(\mathrm{S}):$}

Horibe, Naoto; Tanaka, Hirokazu; Ishiyama, Takuji

\section{CITATION:}

Horibe, Naoto ...[et al]. Selection of Injection Parameters for Various Engine Speeds in PCCI-Based Diesel Combustion with Multiple Injection. SAE Technical Papers 2011: 2011 01-1822.

\section{ISSUE DATE:}

2011-08-30

URL:

http://hdl.handle.net/2433/237657

\section{RIGHT:}

This is the accepted manuscript of the article, which has been published in final form at https://doi.org/10.4271/201101-1822.; The full-text file will be made open to the public on 1 March 2012 in accordance with publisher's 'Terms and Conditions for Self-Archiving'; この論文は出版社版でありません。引用の際には出版社版をご確認ご利用ください。; This is not the published version. Please cite only the published version. 


\title{
Selection of Injection Parameters for Various Engine Speeds in PCCl-Based Diesel Combustion with Multiple Injection
}

\author{
Naoto Horibe, Hirokazu Tanaka and Takuji Ishiyama \\ Kyoto University
}

Copyright $\odot 2011$ Society of Automotive Engineers of Japan, Inc.

\begin{abstract}
The objective of this study is to obtain a strategy for adapting injection and exhaust gas recirculation (EGR) conditions to various engine speeds. An experimental study was conducted using a single-cylinder test engine and varying the injection timings of two-stage injection, the injection-quantity ratio, the EGR rate, and the swirl ratio at low (1300 rpm) and high (2300 rpm) engine speeds. When using base injection conditions, the results indicated that problems occurred for the high maximum pressure rise rate at low engine speed and the low thermal efficiency at high engine speed. At low engine speed, retarding the injection timings and increasing the first-injection quantity ratio reduced the maximum pressure rise rate without sacrificing engine performance. At high engine speed, advancing the injection timings improved the thermal efficiency but increased smoke emission. In addition to advancing the injection timings, a decrease of the first-injection quantity ratio reduced smoke emission.
\end{abstract}

\section{INTRODUCTION}

Premixed charge compression ignition (PCCl) -based diesel combustion is characterized by reduced heterogeneity in the fuel-air mixture concentration and reduced flame temperature by utilizing a long mixing time with moderately early injection, low compression ratio and high EGR rate. This combustion method has been extensively studied $[1,2,3,4,5,6,7,8,9]$ because it is expected to significantly reduce nitrogen oxides (NOx) and particulate matter (PM) emissions under partial-load conditions. In partial load conditions, low exhaust gas temperatures do not activate catalytic converters. Consequently, unburned species emissions such as carbon monoxide (CO) and hydrocarbons $(\mathrm{HC})$ are emitted at high levels due to the low burning gas temperature. In addition, excessively intense combustion causes unacceptable combustion noise when the injection quantity is increased.
Optimizing the fuel-air mixture distribution is one of the countermeasures against the increase in unburned species emissions and combustion noise $[10,11,12,13,14,15]$. A multiple-injection strategy is the most realistic way to control the mixture distribution. Therefore, many studies have been conducted on the optimization of multiple injection to reduce unburned species emissions in PCCl-based combustion. Furthermore, strategies to reduce combustion noise have been investigated $[16,17]$.

In a previous study [16], the authors investigated the selection of injection parameters and EGR rates in two-stage injection to reduce combustion noise (by a low pressure rise rate) with low emissions and high thermal efficiency at a fixed engine speed, and proposed the following injection strategy. At a low load, the first-injection quantity should be decreased to suppress the maximum pressure rise rate and the second injection should be started before ignition of the first-injection fuel. At higher loads, it is necessary to reduce the EGR rate and to advance the first-injection timing to suppress smoke emission and to set the second-injection timing close to top dead center (TDC) in the expansion stroke to suppress the decrease in thermal efficiency. The selected injection and EGR conditions provided drastic improvement of exhaust emissions with a sufficiently low pressure rise rate equivalent to diesel operation with close-pilot injection.

When the engine speed is varied, the above strategy at a fixed speed will require some modifications because the mixture formation and the combustion processes are strongly influenced by the change in in-cylinder flow and cylinder volume history. Nevertheless, few papers have discussed the effects of engine speed in PCCl-based combustion using multiple injections.

Therefore, this study focuses on the selection of injection conditions for various engine speeds in PCCl-based diesel combustion. First, the effects of engine speed on performance and emissions are examined from the results of single-stage injection experiments at low and middle loads. In the next step, 
Table 1 Standard specifications of test engine

\begin{tabular}{|l|c|}
\hline Engine type & $\begin{array}{c}\text { Direct-injection diesel engine, } \\
\text { Naturally aspirated, } \\
\text { Single-cylinder, Water-cooled }\end{array}$ \\
\hline Bore×Stroke & \begin{tabular}{c}
$102 \times 105 \mathrm{~mm}$ \\
\hline Displacement
\end{tabular} \\
\hline Compression ratio & 15.5 \\
\hline $\begin{array}{l}\text { Combustion } \\
\text { chamber }\end{array}$ & Toroidal type with a $\phi 56$ bowl \\
\hline Swirl ratio & 2.6 \\
\hline Injection system & $\begin{array}{c}\text { Common-rail system } \\
\text { (Max. pressure: } 135 \mathrm{MPa})\end{array}$ \\
\hline Injection nozzle & $\phi 0.18$ mm×6 holes-150 deg \\
\hline EGR system & Water-cooled \\
\hline
\end{tabular}

Table 2 Standard experimental conditions

\begin{tabular}{|l|c|}
\hline $\begin{array}{l}\text { Cooling water } \\
\text { temperature (inlet) }\end{array}$ & $80 \mathrm{degC}$ \\
\hline $\begin{array}{l}\text { Lubricating oil } \\
\text { temperature }\end{array}$ & $80 \mathrm{degC}$ \\
\hline Rail pressure & $120 \mathrm{MPa}$ \\
\hline Fuel & $\mathrm{JIS} \mathrm{No.2} \mathrm{diesel} \mathrm{fuel}$ \\
Density (at 15 degC) & $819 \mathrm{~kg} / \mathrm{m}^{3}$ \\
Gross heating value & $46.0 \mathrm{MJ} / \mathrm{kg}$ \\
Cetane Index & 57.8 \\
Sulfur & $6 \mathrm{ppm}$ \\
\hline
\end{tabular}

some problems are selected based on the results of experiments varying engine speed with the base two-stage injection strategy which was obtained in the previous study at a fixed speed. The injection timings of two-stage injection, injection-quantity ratio, EGR rate, and swirl ratio are modified to mitigate the problems at low and high engine speeds. Finally, the injection strategy and its limitations are discussed through the process of optimizing the parameters.

\section{EXPERIMENTAL SETUP}

The experimental system and the measurement methods used in this study were essentially the same as those reported in the previous study [8]. The test engine was a single-cylinder four-stroke-cycle naturally aspirated direct-injection diesel engine (Yanmar NFD170). The standard specifications are listed in Table 1. A common-rail injection system (Denso ECD-U2P) was installed instead of the original injection system. A cooled-EGR system was employed; in this system, the recirculated exhaust gas is cooled to room temperature.

The standard experimental conditions are given in Table 2. For details of other experimental conditions and measurement methods, please refer to the previous study [8].

\section{RESULTS AND DISCUSSION}

\section{EFFECTS OF ENGINE SPEED WITH \\ SINGLE-STAGE INJECTION}

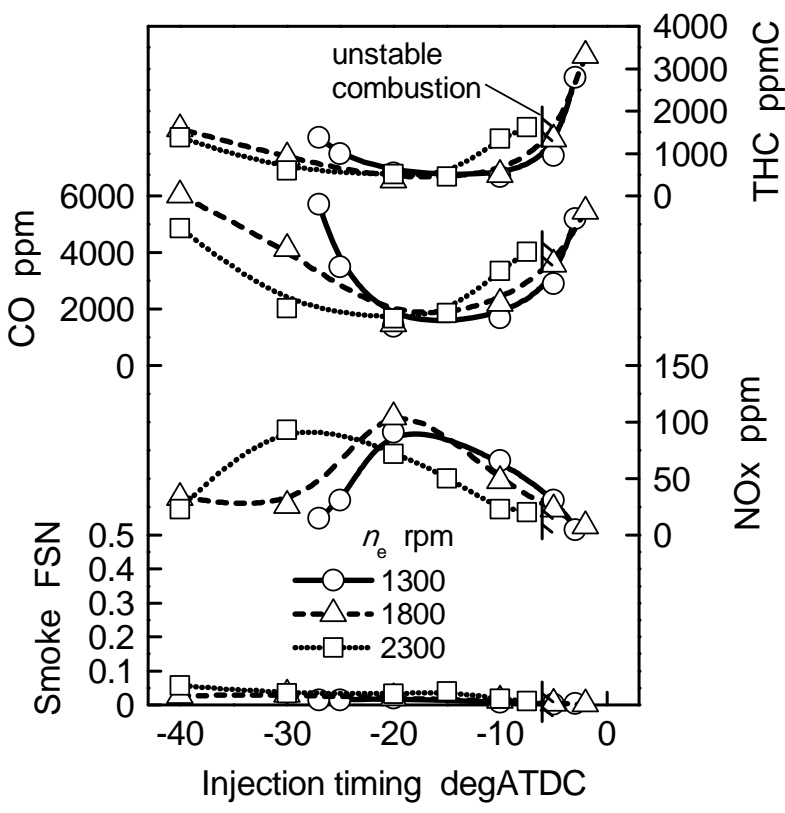

Figure 1 Effects of engine speed on emissions with single-stage injection at a low load $\left(q_{\mathrm{f}}=\right.$ $20 \mathrm{~mm}^{3}, r_{\mathrm{EGR}}=45 \%$ ).

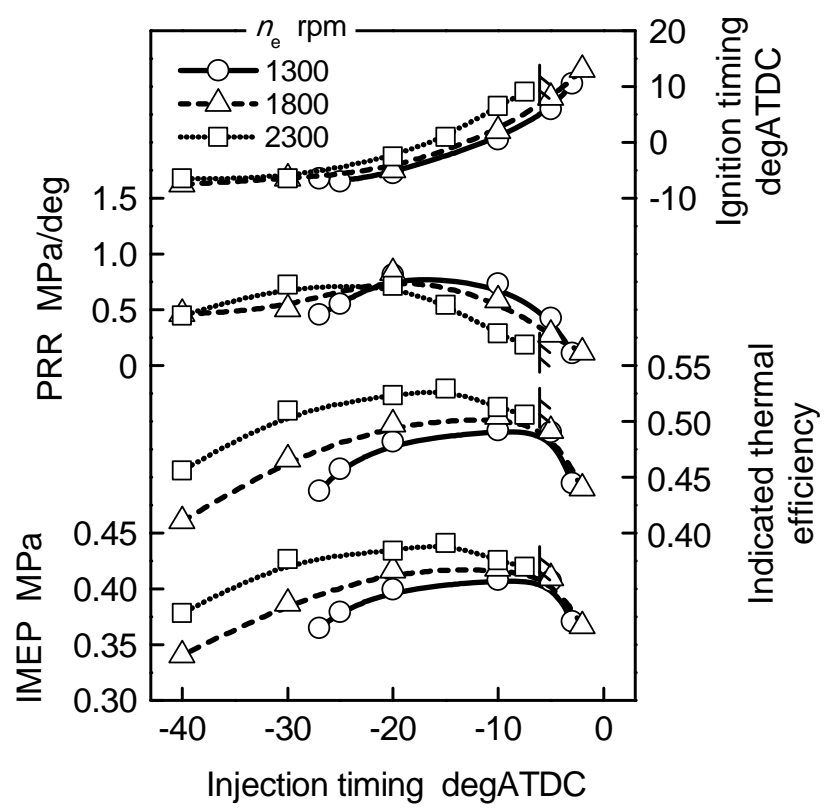

Figure 2 Effects of engine speed on performance with single-stage injection at a low load $\left(q_{\mathrm{f}}=\right.$ $\left.20 \mathrm{~mm}^{3}, r_{\mathrm{EGR}}=45 \%\right)$.

To obtain a basic understanding of the effects of engine speed on performance and emissions, single-stage injection experiments were performed under various engine-speed conditions. The engine speed $n_{\mathrm{e}}$ was set at 1300, 1800, and $2300 \mathrm{rpm}$, and the injection timing was varied for an injection quantity per cycle of 20 and $30 \mathrm{~mm}^{3}$, which correspond to low and middle loads, respectively. The EGR rate was set to $45 \%$ for an injection quantity of $20 \mathrm{~mm}^{3}$ and to $25 \%$ for an injection quantity of $30 \mathrm{~mm}^{3}$ based on the results of the previous study of two-stage injection [16]. 


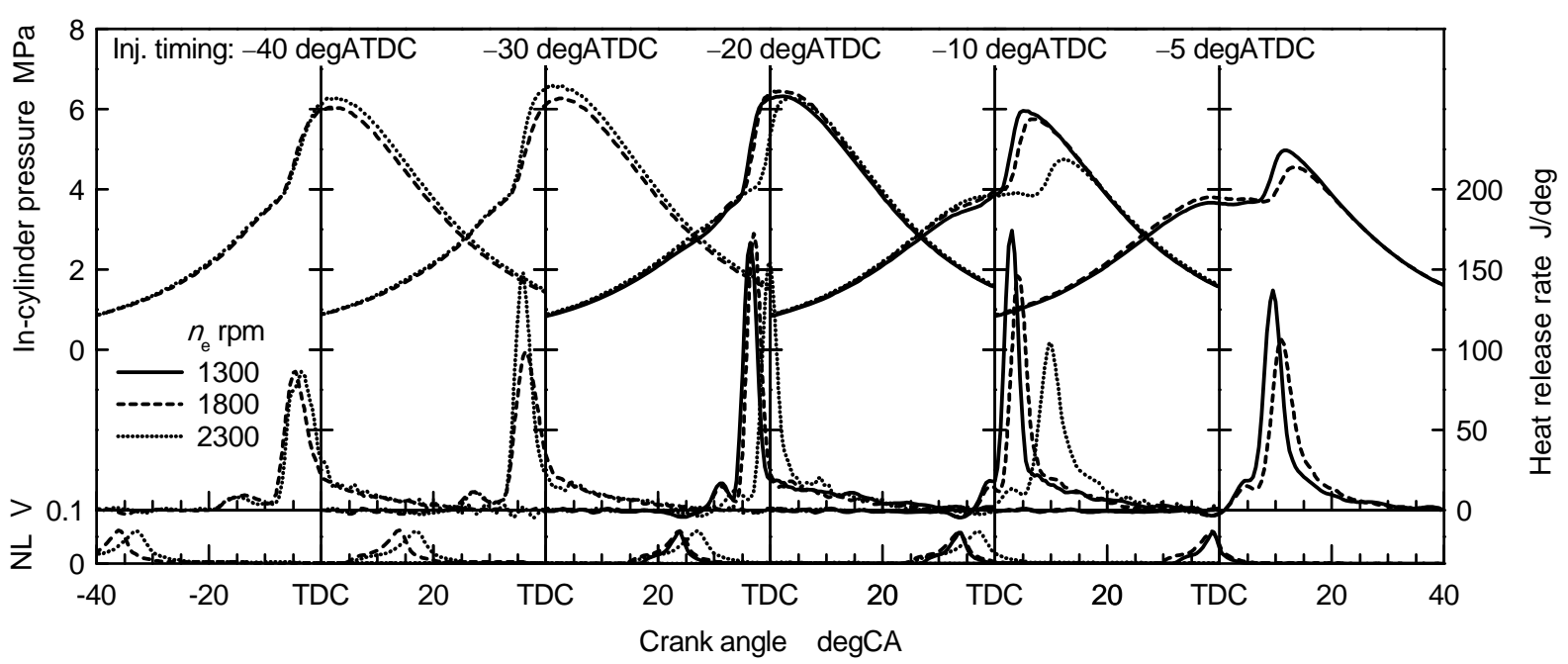

Figure 3 Effects of engine speed on the heat release rate and the in-cylinder pressure with single-stage injection at a low load $\left(q_{\mathrm{f}}=20 \mathrm{~mm}^{3}, r_{\mathrm{EGR}}=45 \%\right)$.

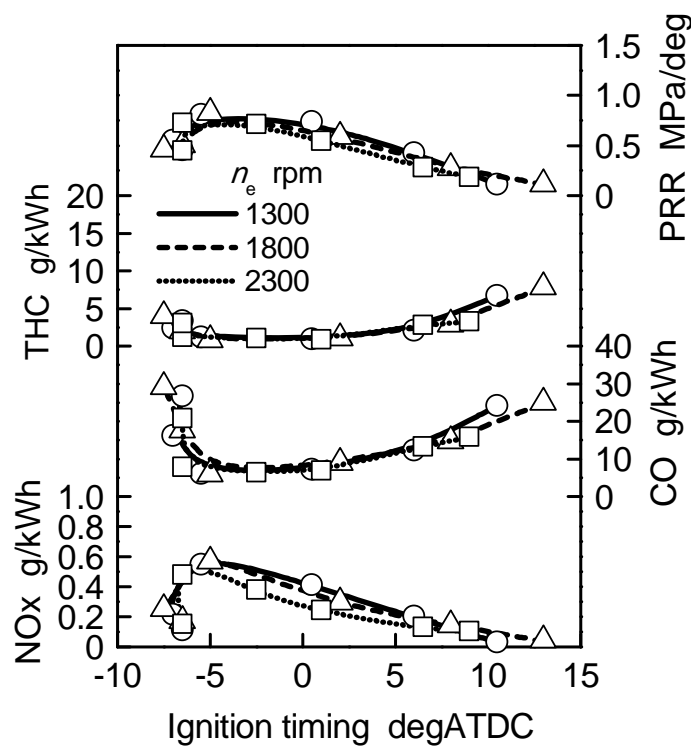

Figure 4 Performance and emissions against ignition timing in the case of single-stage injection at a low load $\left(q_{\mathrm{f}}=20 \mathrm{~mm}^{3}, r_{\mathrm{EGR}}=45 \%\right)$.

\section{Effects of engine speed with single-stage injection at a low load}

An experiment was performed with an injection quantity $q_{\mathrm{f}}$ of $20 \mathrm{~mm}^{3}$ and an EGR rate $r_{\mathrm{EGR}}$ of $45 \%$. Figure 1 shows smoke, NOx, CO, and THC emissions against the injection timing, and Figure 2 shows the indicated mean effective pressure IMEP, indicated thermal efficiency, maximum pressure rise rate PRR, and ignition timing. Figure 3 shows the heat release rate, in-cylinder pressure, and output of needle-lift sensor NL. Ignition timing was defined as the timing when $5 \%$ of the total heat energy of combustion is released.

As shown in Fig. 1, advancing injection timing from TDC to -20 degATDC reduces unburned species emissions such as $\mathrm{CO}$ and THC, although a further advance increases the emissions. As shown in Fig. 3, the heat release takes place in the expansion stroke for injection timings after -20 degATDC, which causes higher unburned species emissions due to the decay of the gas temperature. Especially, for a higher engine speed, the increase in unburned species emissions is distinct because of the delayed heat release.

The trend of NOx is opposite to that of unburned species emissions, as shown in Fig. 1. Smoke is low in all the experiments because the injection quantity is small. As shown in Fig. 2, IMEP and the indicated thermal efficiency are higher for the higher engine speed. This is probably because the cooling heat loss is lowered due to the delayed heat release.

Thus, the change in ignition timing with the variation of engine speed influences performance and emissions. Therefore, the above data are re-plotted against the ignition timing in Figure 4. The emissions data are displayed as the indicated specific emissions. The emissions clearly depend on the ignition timing regardless of the engine speed, although NOx for $2300 \mathrm{rpm}$ is slightly lower at the ignition timing near 0 degATDC (injection timing of -20 to -15 degATDC) due to the lower heat release rate (see Fig. 3).

For the middle load, the experiment was performed with an injection quantity of $30 \mathrm{~mm}^{3}$ and an EGR rate of $25 \%$. Figures 5 and 6 show the emissions and performance against the injection timing. Intense initial combustion restricts the advance of injection timing for every engine speed. The increase in unburned species emissions and the decrease in NOx are observed for the higher engine speed, whereas the higher pressure rise rate is distinct for the lower engine speed. These trends are similar to the case of a low load.

Figure 7 shows the same variable data for ignition timing. The tendencies are similar to the low load case, excluding the maximum pressure rise rate, which is higher at the lower engine speed. This is due to the higher heat release rate at the same ignition timing.

As described above, the change in engine speed influences engine performance and emissions. The 


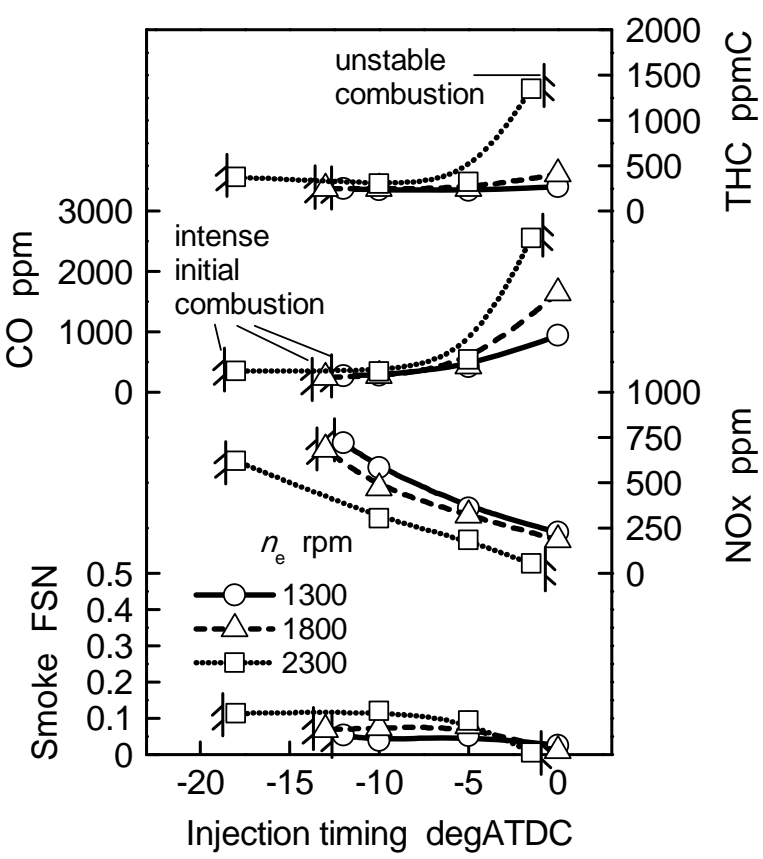

Figure 5 Effects of engine speed on emissions with single-stage injection at a middle load $\left(q_{\mathrm{f}}=\right.$ $30 \mathrm{~mm}^{3}, r_{\mathrm{EGR}}=25 \%$ ).

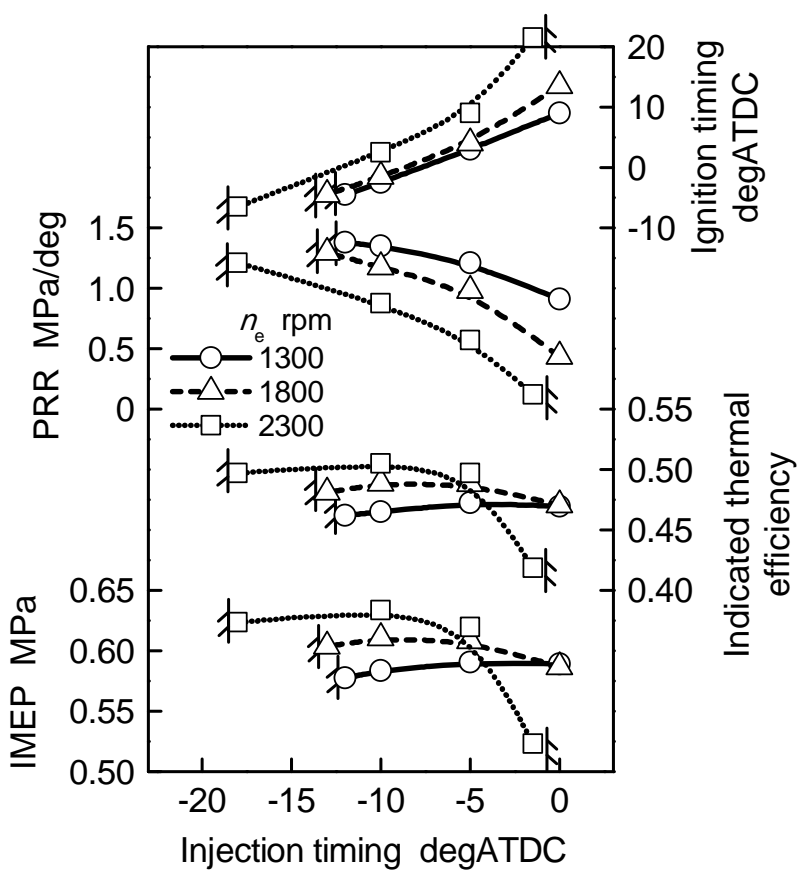

Figure 6 Effects of engine speed on performance with single-stage injection at a middle load $\left(q_{\mathrm{f}}=\right.$ $30 \mathrm{~mm}^{3}, r_{\mathrm{EGR}}=25 \%$ ).

reason can be mostly explained based on the change in the ignition delay and the heat release rate.

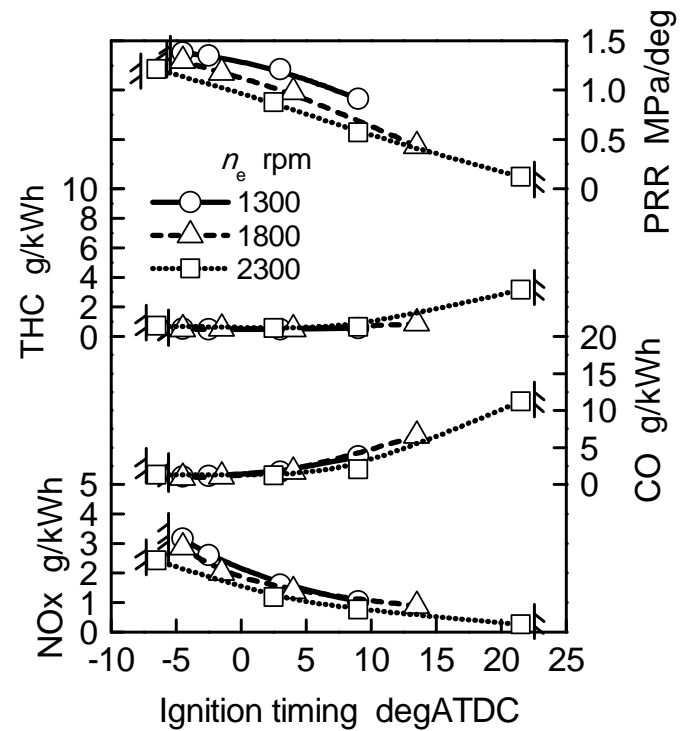

Figure 7 Performance and emissions against ignition timing in the case of single-stage injection at a middle load $\left(q_{\mathrm{f}}=30 \mathrm{~mm}^{3}, r_{\mathrm{EGR}}=\right.$ 25\%).

\section{EFFECTS OF ENGINE SPEED WITH TWO-STAGE INJECTION - BASELINE TEST -}

In PCCl-based combustion, the multiple-injection strategy effectively suppresses the maximum pressure rise rate and lowers the unburned species emission. In a previous study on two-stage injection [16], drastic improvement of emissions with sufficiently low pressure rise rates is provided by selecting the second-injection timing close to TDC in the expansion stroke and advancing the first-injection timing as the engine load increases. According to the results in the previous section, the ignition timing is influenced by engine speed when setting the injection timing near TDC. Therefore, the proper injection conditions change according to the engine speed. To reveal the problems to be solved, the baseline experiment with two-stage injection was first carried out at a fixed injection and EGR condition for all engine speeds.

The injection conditions and EGR rate selected for $1800 \mathrm{rpm}$ in previous study [16] are employed for every engine speed. The conditions are listed in Table 3. Figure 8 shows the performance and emissions, and Figure 9 indicates the pressure and heat release rate of the injection quantity of 20 and $30 \mathrm{~mm}^{3}$. In the case of $1300 \mathrm{rpm}$, the ignition delay and emissions are not much different from those of $1800 \mathrm{rpm}$, but the initial heat release for an injection quantity of $30 \mathrm{~mm}^{3}$ is higher and, therefore, the maximum

Table 3 Selected conditions of two-stage injection at $1800 \mathrm{rpm}$ in the previous study [16]

\begin{tabular}{|c|c|c|c|c|}
\hline $\begin{array}{c}\text { Inj. quantity } \\
\mathrm{mm}^{3}\end{array}$ & Inj. quantity ratio & $\begin{array}{c}\text { First-inj. timing } \\
\text { degATDC }\end{array}$ & $\begin{array}{c}\text { Second-inj. timing } \\
\text { degATDC }\end{array}$ & $\begin{array}{c}\text { EGR rate } \\
\%\end{array}$ \\
\hline \hline 20 & $5 / 15$ & -20 & -5 & 45 \\
\hline 25 & $5 / 20$ & -20 & 5 & 35 \\
\hline 30 & $5 / 25$ & -25 & 5 & 25 \\
\hline 35 & $5 / 30$ & -30 & 5 & 25 \\
\hline
\end{tabular}




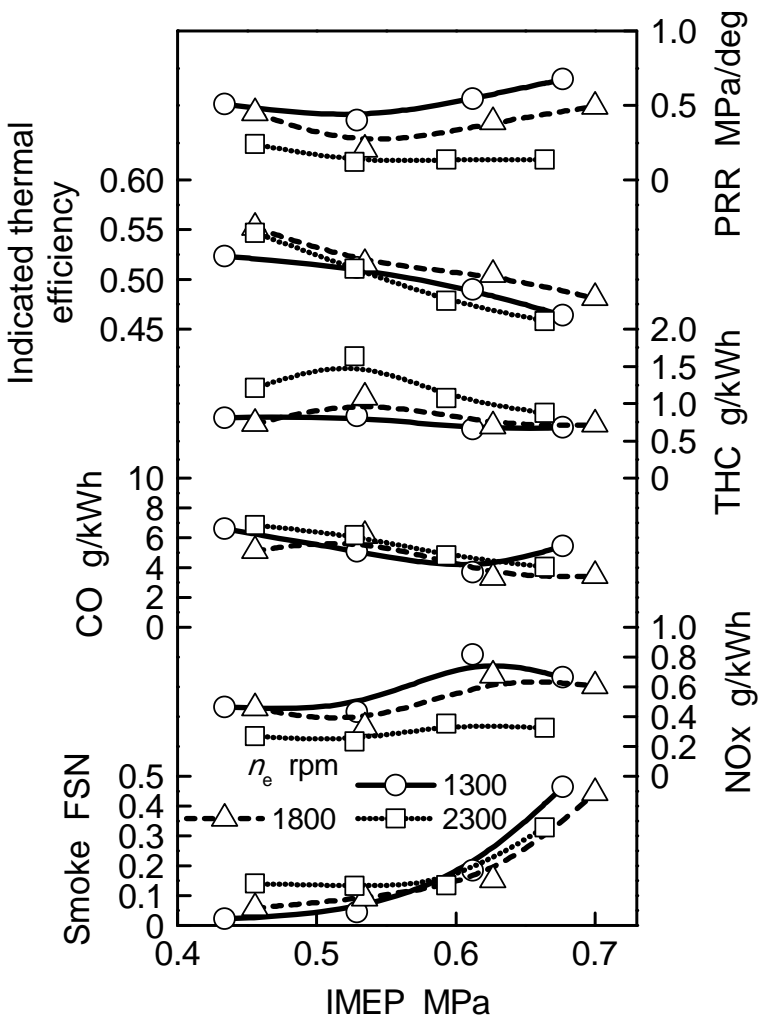

Figure 8 Effects of engine speed on performance and emissions under baseline injection conditions.

pressure rise rate is higher. In the case of $2300 \mathrm{rpm}$, the heat release is delayed compared with $1800 \mathrm{rpm}$, which leads to lower thermal efficiency at high loads, and the emission level of $\mathrm{HC}$ is higher at low loads. These tendencies are similar to the case of single-stage injection, excluding the lower thermal efficiency for the higher engine speed, because the ignition timing is much later than that in the single-injection case.

To suppress the maximum pressure rise rate at low engine speed and to improve the thermal efficiency at high engine speed, the effects of injection timings, injection quantity ratio, EGR rate, and swirl ratio are examined at low and high engine speeds.

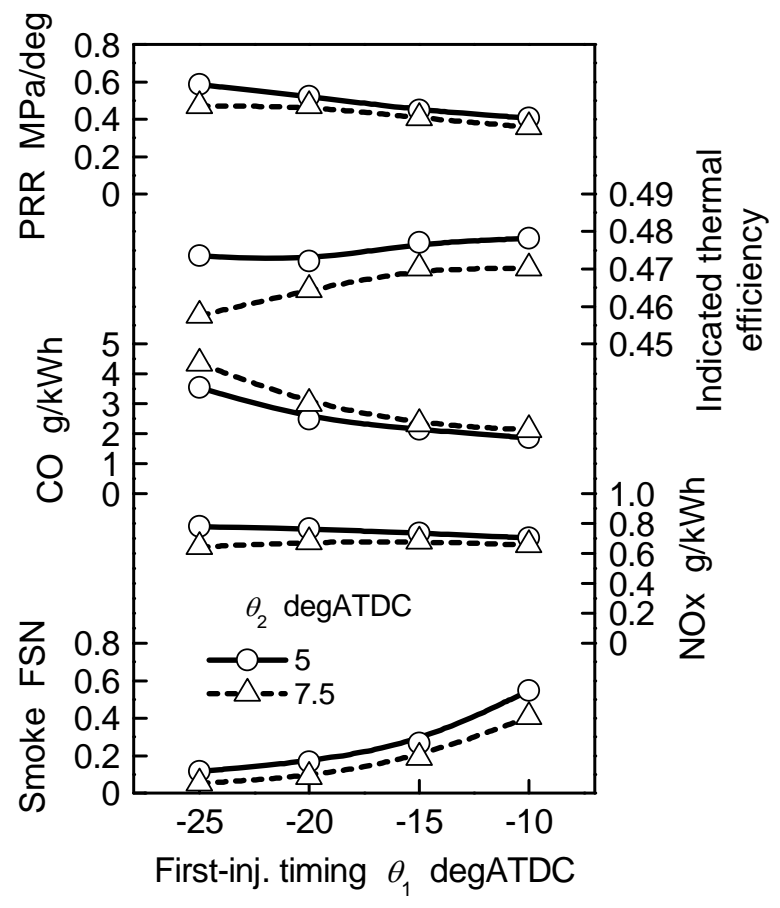

Figure 10 Effects of injection timings on performance and emissions at $1300 \mathrm{rpm}\left(q_{1} / q_{2}=\right.$ $\left.5 / 25, r_{\mathrm{EGR}}=25 \%\right)$.

The experiments are performed at a middle load (injection quantity of $30 \mathrm{~mm}^{3}$ ) because it would be difficult to improve the engine performance and emissions due to the strong tendency toward smoke emission when using two-stage injection.

\section{IMPROVEMENT OF PERFORMANCE AND EMISSIONS UNDER A LOW ENGINE SPEED CONDITION}

Effects of injection timings under a low engine speed

In the case of $1800 \mathrm{rpm}$ [16] under a fixed first-injection quantity condition, a late first injection effectively suppresses the maximum pressure rise rate because a later first injection increases the amount of heat release, which leads to a shorter ignition delay of the second injection. Late second

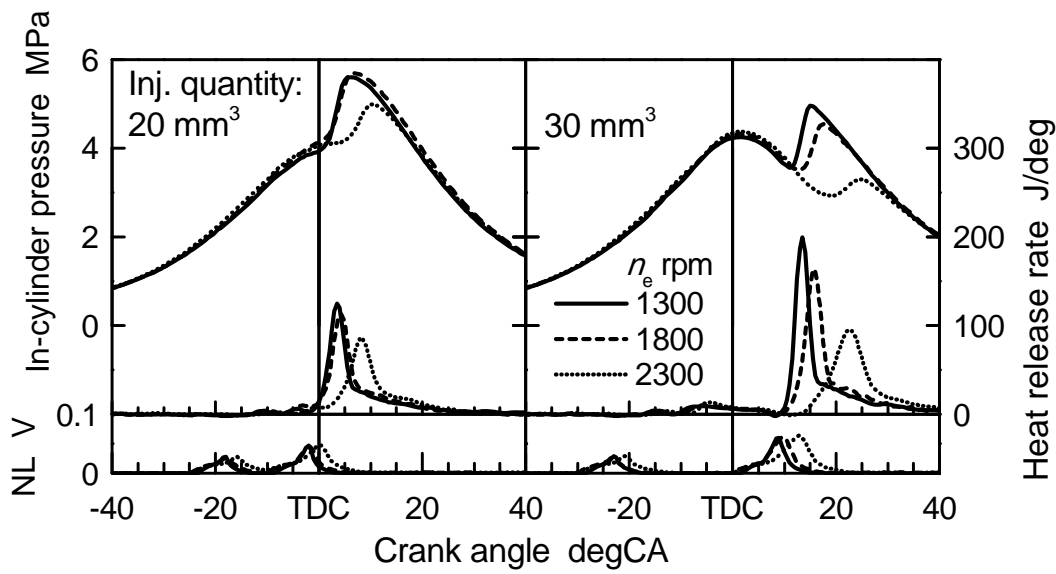

Figure 9 Effects of engine speed on heat release rate and in-cylinder pressure under baseline injection conditions $\left(q_{\mathrm{f}}=20,30 \mathrm{~mm}^{3}\right)$. 


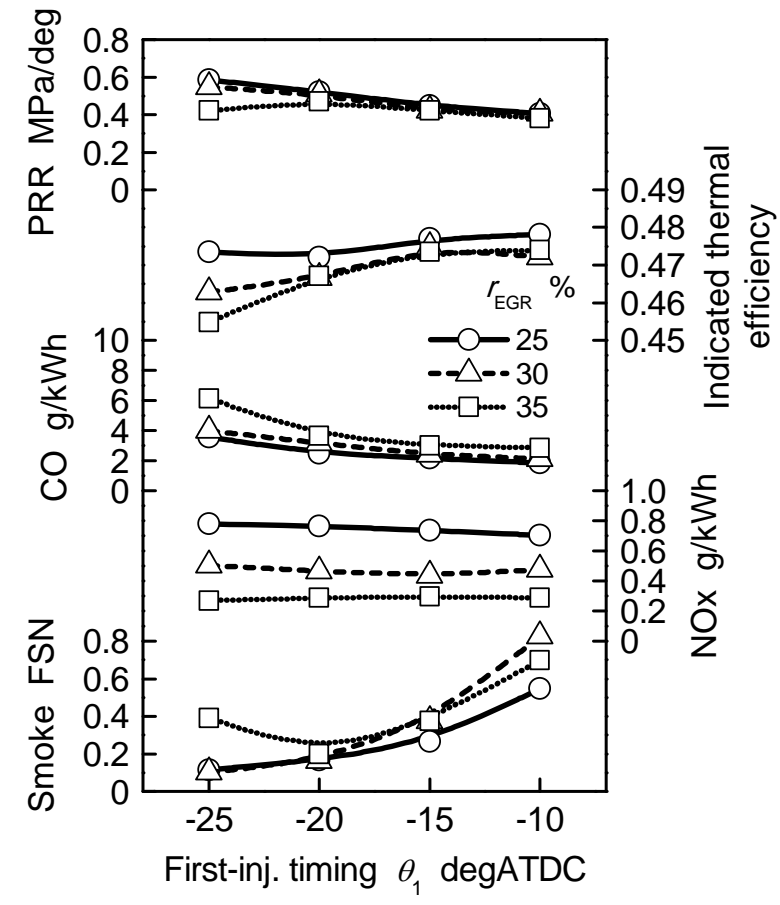

Figure 11 Effects of EGR rate on performance and emissions at $1300 \mathrm{rpm}\left(q_{1} / q_{2}=5 / 25, \theta_{2}=\right.$ $5 \operatorname{deg}$ ATDC).

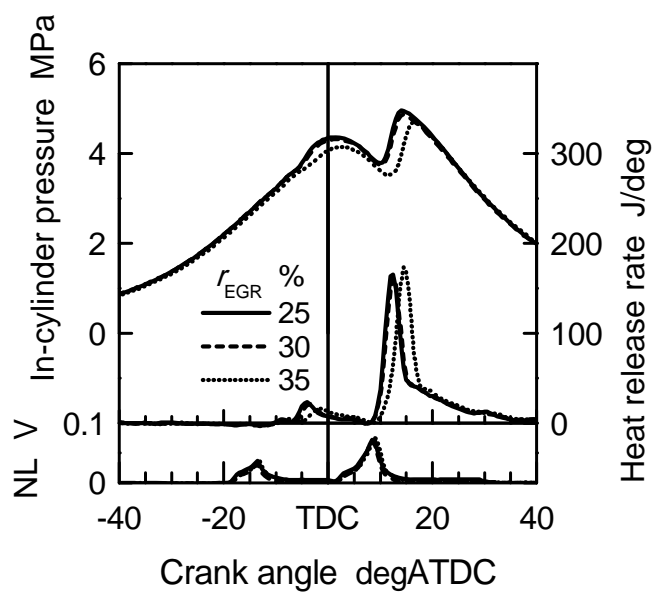

Figure 12 Effects of EGR rate on heat release rate and in-cylinder pressure at $1300 \mathrm{rpm}\left(q_{1} / q_{2}=\right.$ $5 / 25, \theta_{1}=-15 \operatorname{deg}$ ATDC, $\theta_{2}=5 \operatorname{deg}$ ATDC).

injection also effectively suppresses the maximum pressure rise rate because the heat-release timing is retarded to the expansion stroke. This would be effective for solving the problem at low engine speed. Therefore, experiments were performed by varying the first- and second-injection timings. First-injection timing $\theta_{1}$ was varied from -25 to -10 degATDC. Second-injection timing $\theta_{2}$ was 5 and 7.5 degATDC. Further retarding of the second injection severely deteriorated the thermal efficiency.

Figure 10 shows effects of the first-injection timing on performance and emissions. Because the tendencies of $\mathrm{HC}$ and $\mathrm{CO}$ emissions are almost identical, only $\mathrm{CO}$ is displayed to represent the unburned species emissions. As is expected, retarding both first- and second-injection timing lowers the maximum pressure rise rate. However, the later first injection increases the smoke emission because it raises the in-cylinder pressure and temperature at the second-injection start, as in the case of $1800 \mathrm{rpm}$, which causes shorter ignition delay of the second injection. The later second injection reduces not only the pressure rise rate but also NOx and smoke, while it decreases thermal efficiency significantly.

\section{Effects of EGR rate under a low engine speed condition}

Reduction of the maximum pressure rise rate was attempted by increasing the EGR rate. In this experiment, second-injection timing $\theta_{2}$ was fixed at 5 degATDC, and first-injection timing $\theta_{1}$ and EGR rate $r_{\mathrm{EGR}}$ were varied from -25 to $-10 \mathrm{degATDC}$ and from $25 \%$ to $35 \%$, respectively. Figure 11 shows the performance and emissions, and Figure 12 shows the heat release rate. As shown in Fig. 11, the increase in EGR rate reduces NOx emission and increases $\mathrm{CO}$ and smoke emissions. Contrary to expectations, in most cases, increasing the EGR rate does not effectively reduce the maximum pressure rise rate, because the heat release rate is not reduced although it is delayed when the EGR rate increases, as shown in Fig. 12. In the case of first-injection timing of -25 degATDC, the amount of heat release of first-stage combustion is decreased by the increase in the EGR rate to $35 \%$ and the peak of the heat release by a second injection is remarkably delayed and reduced. Accordingly, the maximum pressure rise rate can be suppressed, but the $\mathrm{CO}$ emission significantly increases. Thus, the increase in EGR rate is not effective for reduction of the pressure rise rate under the range of conditions in this study.

\section{Effects of injection quantity ratio rate under a low engine speed condition}

In the above experiments, since the first-injection quantity is small $\left(5 \mathrm{~mm}^{3}\right)$, the maximum pressure rise rate depends on second-injection combustion. The reduction of the second-injection quantity is effective for lowering the maximum pressure rise rate. Therefore, an experiment was performed that varied the injection quantity ratio $q_{1} / q_{2}$ from $5 / 25$ to $10 / 20$. Second-injection timing $\theta_{2}$ and EGR rate $r_{\mathrm{EGR}}$ were fixed at 5 degATDC and 25\%, respectively. First-injection timing $\theta_{1}$ was varied from -25 to -10 degATDC.

Figure 13 shows the performance and emissions, and Fig. 14 shows the heat release rate with first-injection timing of -20 degATDC. As shown in Fig. 13, the increased first-injection quantity (the ratio of $7 / 23$ ) reduces the maximum pressure rise rate and the NOx emission, but it increases the smoke emission. This is because the amount of oxygen entrained into the second-injection spray decreases due to the increased oxygen consumption in the first-stage combustion. Further reduction of the second-injection quantity to $20 \mathrm{~mm}^{3}$ (a ratio of 10/20) significantly increases smoke emission even with the early first injection because the large heat release by the first injection raises in-cylinder pressure and temperature, which advances the ignition of the second injection, as 


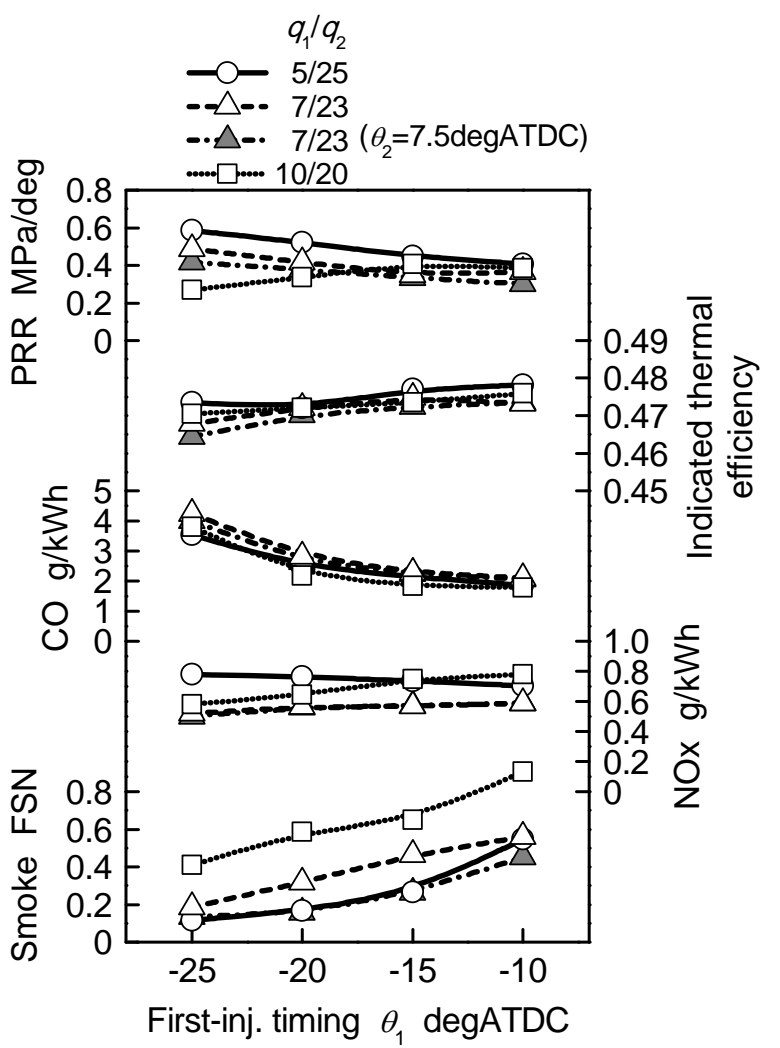

Figure 13 Effects of injection-quantity ratio on performance and emissions at $1300 \mathrm{rpm}\left(\theta_{2}=\right.$ $5 \operatorname{degATDC}, r_{\mathrm{EGR}}=25 \%$ ).

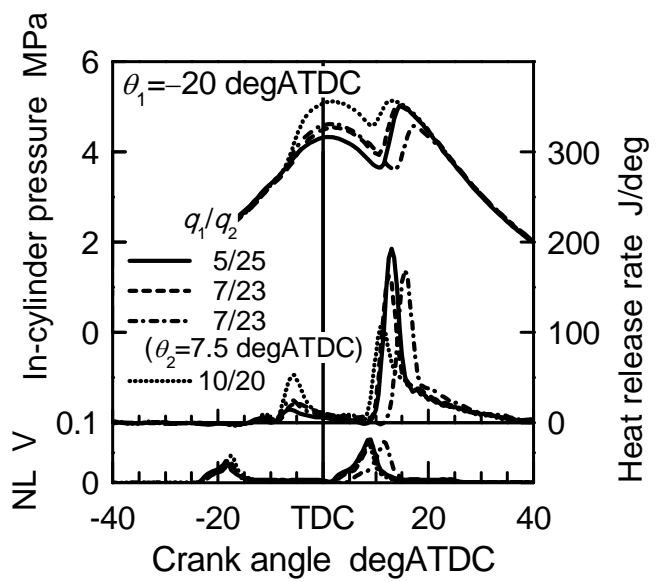

Figure 14 Effects of injection-quantity ratio on heat release rate and in-cylinder pressure at $1300 \mathrm{rpm}\left(\theta_{1}=-20 \operatorname{deg}\right.$ ATDC, $\theta_{2}=5 \mathrm{degATDC}, r_{\mathrm{EGR}}$ $=25 \%)$.

shown in Fig. 14. In this case, retarding the first injection increases the maximum pressure rise rate and NOx, unlike that seen in other injection quantity ratios, because the maximum pressure rise rate depends on the first-injection combustion.

The injection quantity ratio of $7 / 23$ can suppress the maximum pressure rise rate without significant deterioration of performance and emissions, except for a slight increase in smoke emission. In the previous study, we found that late second injection could reduce smoke emission. Therefore, an experiment was performed with a later

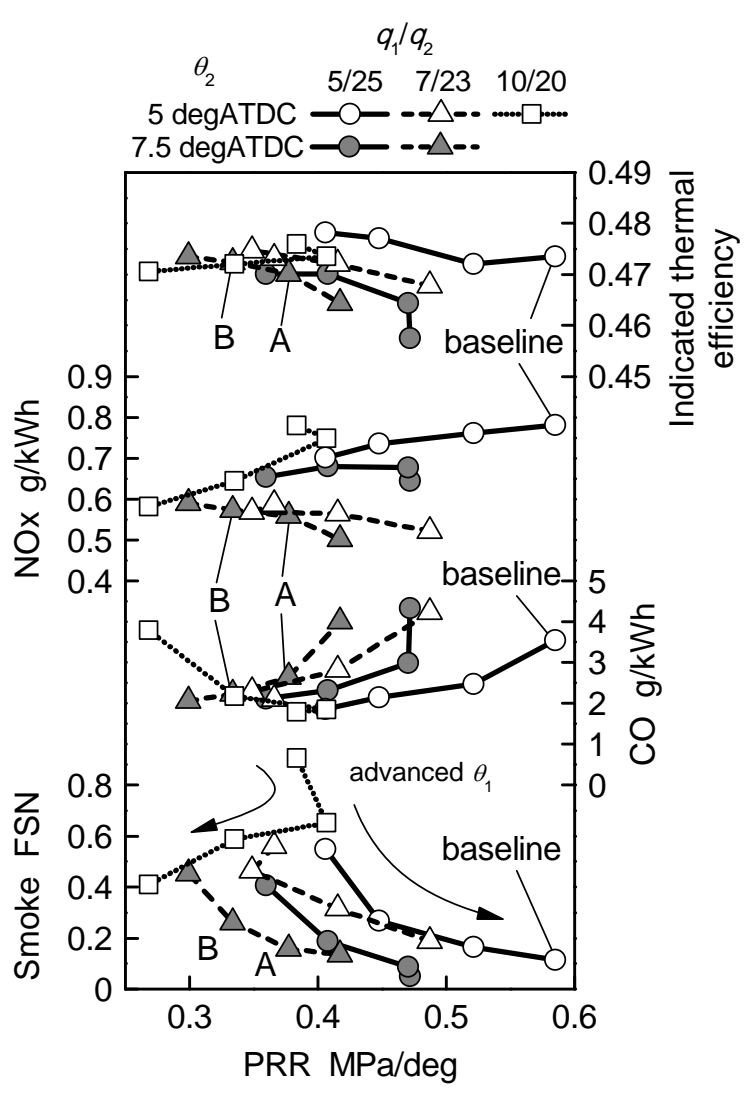

Figure 15 Effects of injection conditions on relationships between maximum pressure rise rate, smoke, CO, NOx, and indicated thermal efficiency at $1300 \mathrm{rpm}\left(r_{\mathrm{EGR}}=25 \%\right)$.

second-injection at an injection quantity ratio of $7 / 23$. To avoid the deterioration of thermal efficiency, the second-injection timing was set to 7.5 degATDC. The results are indicated in Figs. 13 and 14. The smoke emission and the maximum pressure rise rate are lower compared those of the second-injection timing of 5 degATDC. These results coincide with those in Fig. 10, but the impact on NOx, CO, and the thermal efficiency is less. This is probably because the second-injection quantity is smaller.

Selection of injection parameters for a low engine speed

The results up to this point are analyzed to derive the proper selection of injection parameters for the engine speed of $1300 \mathrm{rpm}$. Figure 15 shows NOx, smoke, CO, and indicated thermal efficiency against maximum pressure rise rate. The results of the varying EGR rate are not displayed because no improvement was obtained. To suppress the maximum pressure rise rate at a practical level (under $0.5 \mathrm{MPa} / \mathrm{deg}$ ) with low smoke emission, second-injection timing $\theta_{2}$ should be 7.5 degATDC. Injection quantity ratio $q_{1} / q_{2}$ of $7 / 23$ with a second injection of $7.5 \mathrm{deg} A T D C$ is preferable in terms of NOx and the indicated thermal efficiency. In this case, smoke emission can be reduced by advancing the first-injection timing, but advancing the timing to $-25 \operatorname{degATDC}$ significantly increases $\mathrm{CO}$ emission. Therefore, first-injection timing should be $-20 \operatorname{degATDC}$ (marked as A in Fig. 15) or $-15 \operatorname{deg} A T D C$ (marked as B). Thus, by selecting the injection parameters, NOx emission is 


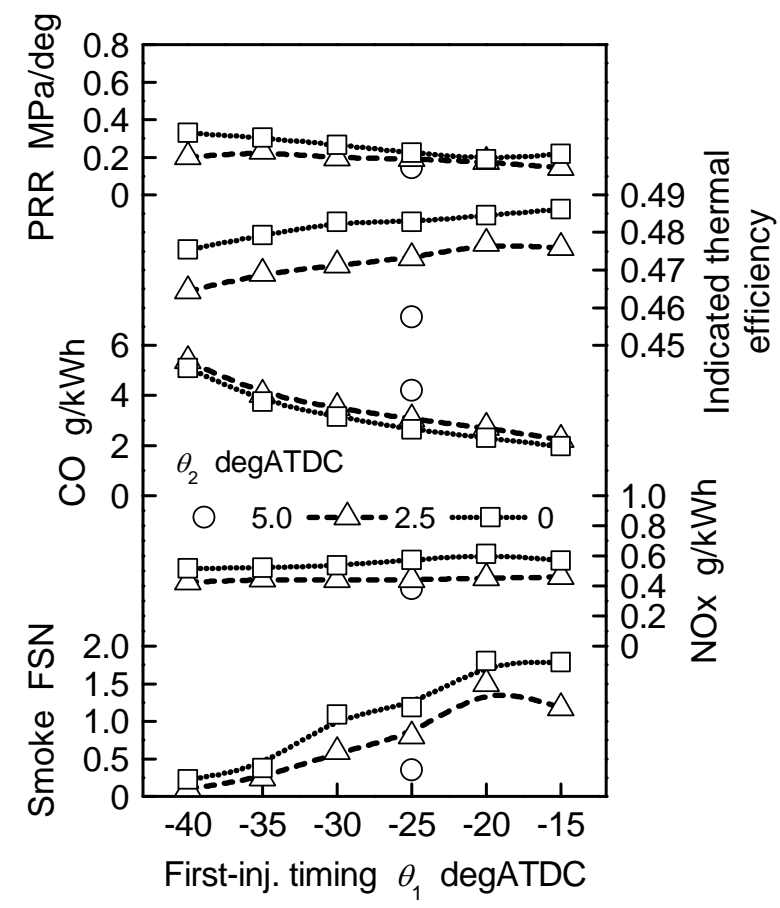

Figure 16 Effects of injection timings on performance and emissions at $2300 \mathrm{rpm}\left(q_{1} / q_{2}=\right.$ $\left.5 / 25, r_{\mathrm{EGR}}=25 \%\right)$.

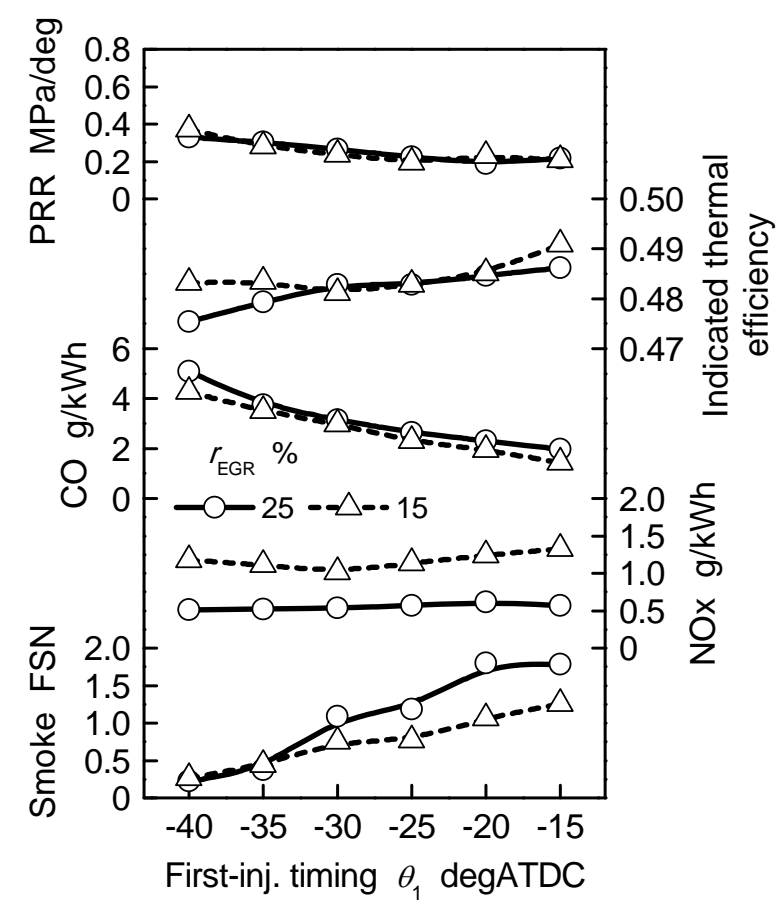

Figure 17 Effects of EGR rate on performance and emissions at $2300 \mathrm{rpm}\left(q_{1} / q_{2}=5 / 25, \theta_{2}=\right.$ TDC $)$.

lower and the decrease of thermal efficiency is smaller compared that of the baseline case.

\section{SELECTION OF INJECTION PARAMETERS AT A HIGH ENGINE SPEED}

Effects of injection timings under a high engine speed condition

Employing the baseline injection conditions for $2300 \mathrm{rpm}$, the heat release is delayed compared with
$1800 \mathrm{rpm}$, which leads to lower thermal efficiency at high loads and higher emission of unburned species at low loads (see Figs. 8 and 9). An experiment was performed with advanced second injection $\theta_{2}$ of 0 degATDC to accelerate the heat release. When the second injection is advanced, the smoke emission increases, judging from the results discussed above, so the first injection is also advanced. Injection quantity ratio $q_{1} / q_{2}$ and EGR rate $r_{\mathrm{EGR}}$ are kept at baseline conditions of $5 / 25$ and $25 \%$.

Figure 16 shows smoke, NOx, $\mathrm{CO}$, indicated thermal efficiency, and maximum pressure rise rate against first-injection timing $\theta_{1}$. The advance of the second injection improves thermal efficiency but increases smoke emission. The advance of the first injection can reduce smoke but increases $\mathrm{CO}$. Other measures are necessary to suppress both smoke and $\mathrm{CO}$ emissions.

\section{Effects of EGR rate under a high engine speed condition}

In the case of low engine speed, the elevation EGR rate increases both smoke and $\mathrm{CO}$ emissions, as in Fig. 11. Conversely, the decrease in EGR rate reduces both smoke and $\mathrm{CO}$ emissions but increases NOx emission. To examine the effect of EGR at a high engine speed, an experiment was performed by decreasing the EGR rate $r_{\mathrm{EGR}}$ from $25 \%$ to $15 \%$. Second-injection timing $\theta_{2}$ was set at 0 degATDC to keep the high thermal efficiency. First-injection timing $\theta_{1}$ was varied in the range from -40 to -15 degATDC.

Figure 17 shows the performance and emissions. The decrease in the EGR rate reduces both smoke and CO emissions, except for cases with early first injection, but significantly increases NOx emission. The change of the EGR rate does not effectively improve the engine performance and emissions, as in the case of low engine speed. Effects of injection quantity ratio rate under a high
engine speed condition

As already mentioned, the ignition delay of the second injection is lengthened and the smoke emission is low when the amount of heat release by the first-injection fuel decreases. Therefore, an experiment was performed to select the proper injection quantity ratio $q_{1} / q_{2}$ to reduce smoke. First-injection quantity $q_{1}$ was decreased to $3 \mathrm{~mm}^{3}$. Second-injection timing $\theta_{2}$ was set at 0 degATDC. First-injection timing $\theta_{1}$ was varied in the range of -40 to -15 degATDC.

Figure 18 shows the performance and emissions. Figure 19 shows the heat release rate. As is expected, the decrease in the first-injection quantity reduces smoke emission to less than half the level because the ignition of the second injection is delayed due to the decrease in the amount of heat release by the first-injection fuel. The delay reduces NOx emission but considerably deteriorates thermal efficiency and increases $\mathrm{CO}$ emission. 


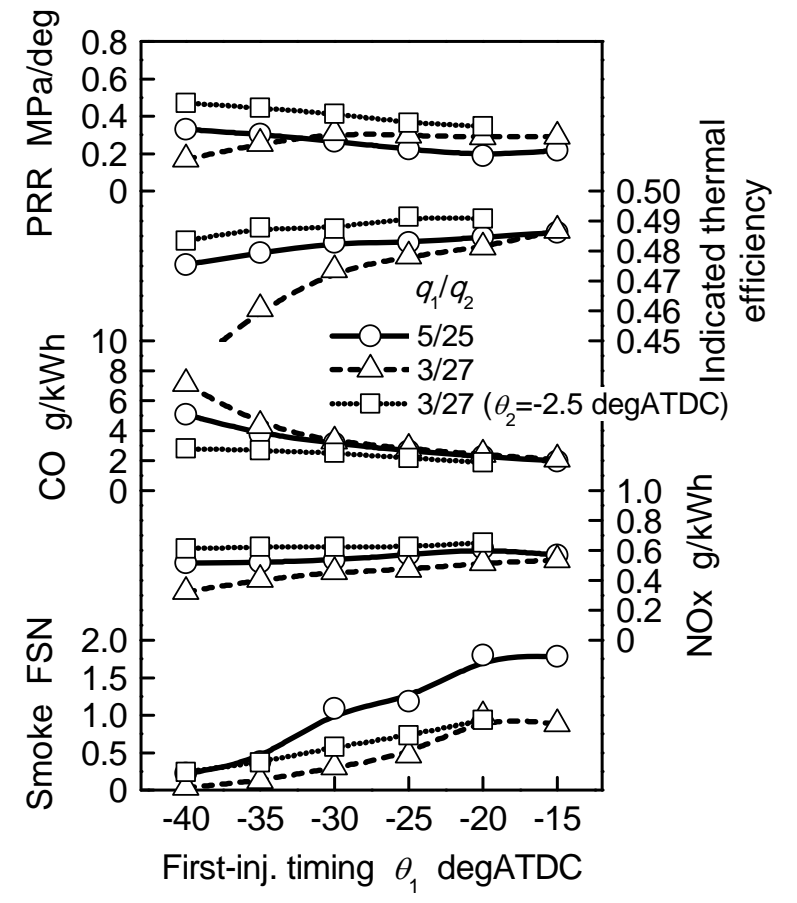

Figure 18 Effects of injection-quantity ratio on performance and emissions at $2300 \mathrm{rpm}\left(\theta_{2}=\right.$ TDC $\left.r_{\mathrm{EGR}}=25 \%\right)$.

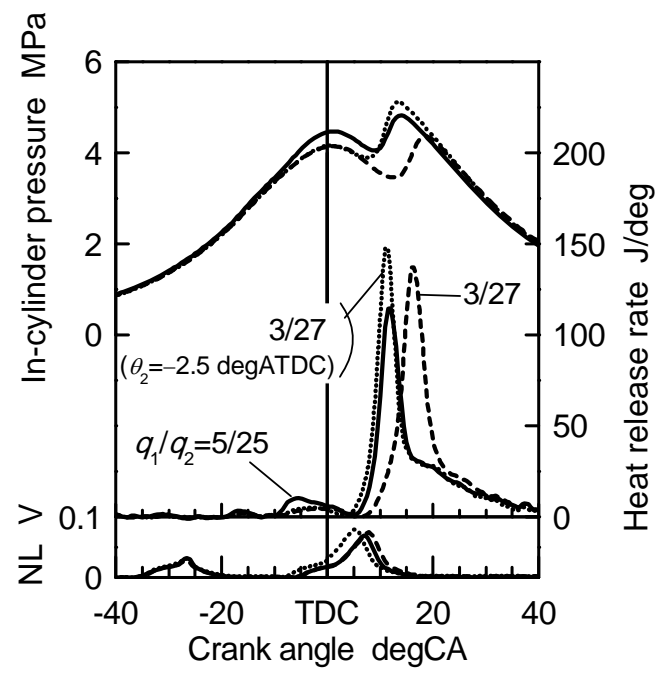

Figure 19 Effects of injection-quantity ratio on heat release rate and in-cylinder pressure at $2300 \mathrm{rpm}\left(\theta_{2}=\mathrm{TDC}, r_{\mathrm{EGR}}=25 \%\right)$.

To improve thermal efficiency, another experiment was performed using the advanced second-injection timing of -2.5 degATDC. The results are displayed in Figs. 18 and 19. The thermal efficiency is significantly improved and the CO emission is lowered, whereas the maximum pressure rise rate, NOx, and smoke increased.

\section{Effects of swirl ratio under a high engine speed condition}

To reduce smoke with the aid of in-cylinder air motion, an experiment was performed with a higher swirl ratio $r_{\text {sw }}$ of 3.1. Injection quantity ratio $q_{1} / q_{2}$ and second-injection timing $\theta_{2}$ were set at $3 / 27$ and -2.5 degATDC, respectively. EGR ratio $r_{\mathrm{EGR}}$ was set at

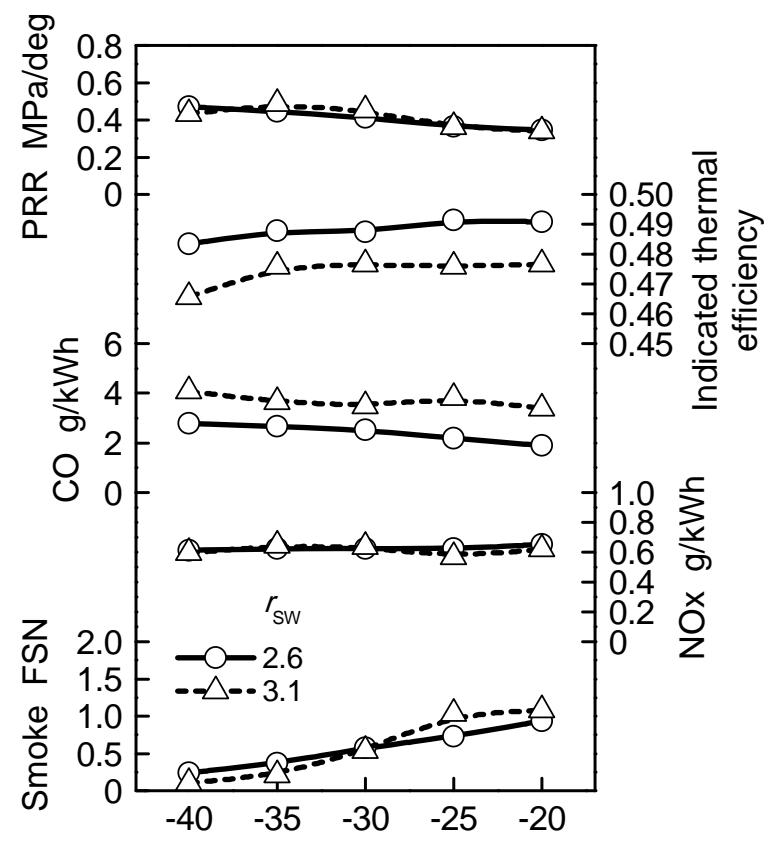

First-inj. timing $\theta_{1}$ degATDC

Figure 20 Effects of swirl ratio on performance and emissions at $2300 \mathrm{rpm}\left(q_{1} / q_{2}=3 / 27, \theta_{2}=\right.$ $\left.-2.5 \operatorname{deg} A T D C, r_{\mathrm{EGR}}=25 \%\right)$.

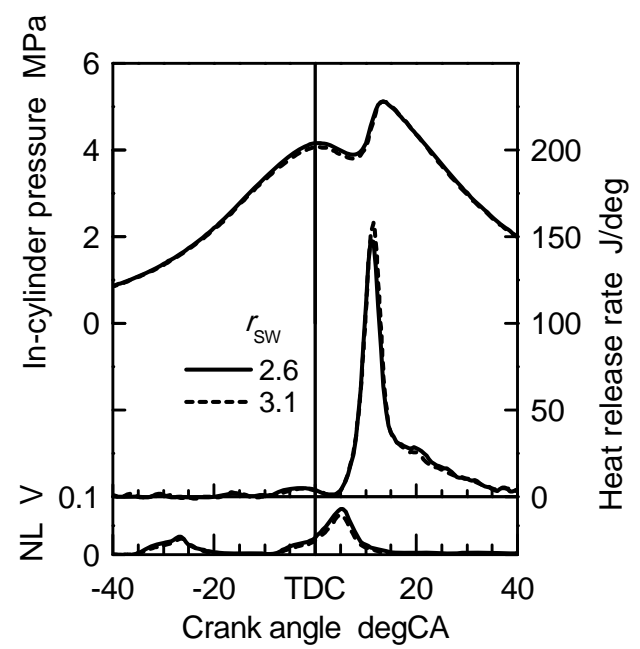

Figure 21 Effects of swirl ratio on heat release rate and in-cylinder pressure at $2300 \mathrm{rpm}\left(q_{1} / q_{2}=\right.$ $3 / 27, \theta_{2}=-2.5 \operatorname{deg}$ ATDC, $\left.r_{\mathrm{EGR}}=25 \%\right)$.

$25 \%$. Figures 20 and 21 show the results. NOx and smoke are not influenced by the swirl ratio. The in-cylinder pressure and the heat release rate are also not influenced, as shown in Fig. 21. In contrast, the thermal efficiency decreases and the $\mathrm{CO}$ emission increases. This is probably because stronger swirl flow increases the cooling heat loss.

Selection of injection parameters for a high engine speed

The above results are analyzed to obtain the proper selection of injection conditions for an engine speed of 2300 rpm. Figure 22 shows NOx, CO, maximum pressure rise rate and indicated thermal efficiency against smoke emission. The results of varying the EGR rate and the swirl ratio are not included because 


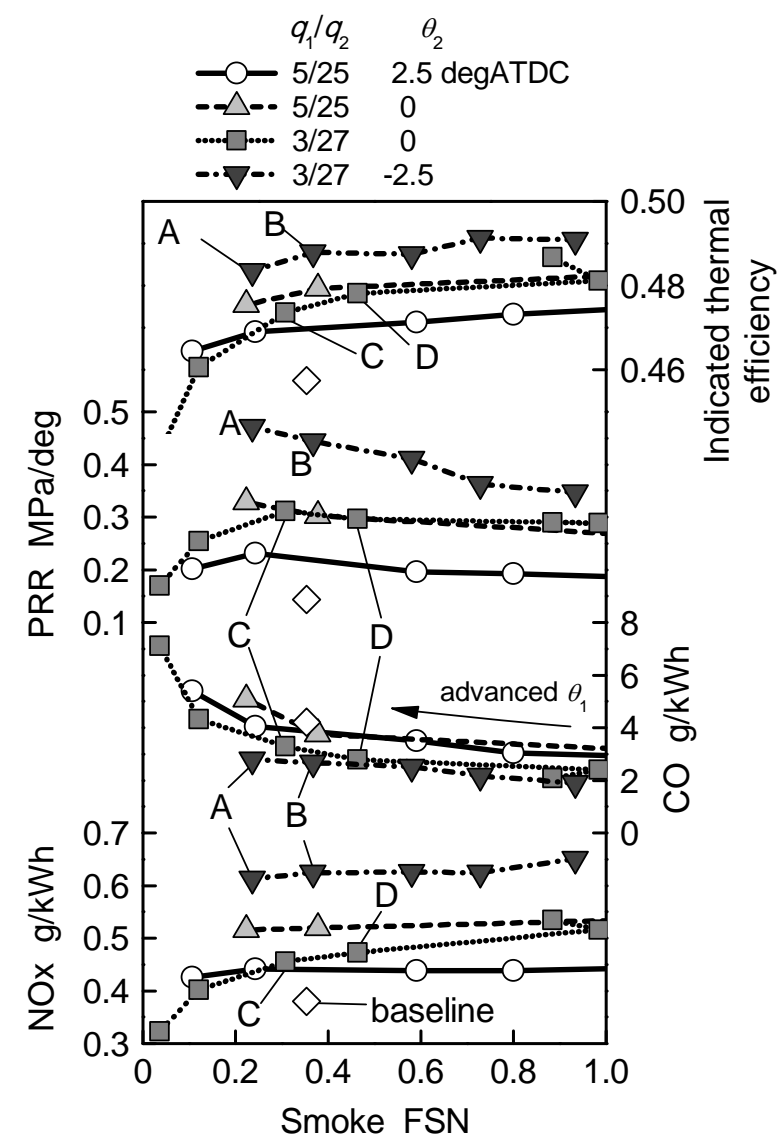

Figure 22 Effects of injection conditions on relationships between maximum pressure rise rate, smoke, CO, NOx, and indicated thermal efficiency at $2300 \mathrm{rpm}\left(r_{\mathrm{EGR}}=25 \%\right)$.

they did not effectively improve performance and emissions. The advance of the first injection is advantageous for reducing smoke emission. However, there is a trade-off relation between $\mathrm{CO}$ and smoke. It is preferable to moderately decrease the first-injection quantity to improve this relation. Especially, conditions marked as A, B, C, and D in Fig. 22 effectively reduce both $\mathrm{CO}$ and smoke. In these conditions, condition $\mathrm{B}$ $\left(\theta_{1}=-35 \operatorname{degATDC}, \theta_{2}=-2.5 \operatorname{deg}\right.$ ATDC) is appropriate when maximum attention is paid to the improvement of thermal efficiency while permitting a certain level of increase in NOx and the maximum pressure rise rate. The condition $\mathrm{C}\left(\theta_{1}=\right.$ $-30 \operatorname{deg}$ ATDC, $\theta_{2}=0$ degATDC) is appropriate when the reduction of NOx and pressure rise rate is maximized.

Finally, selected conditions based on the above discussion for each engine speed are listed in Table 4. The condition ' $A$ ' in Fig. 16 and ' $C$ ' in Fig. 22 are selected for 1300 and $2300 \mathrm{rpm}$, respectively. Figure 23 shows the experimental results under selected and

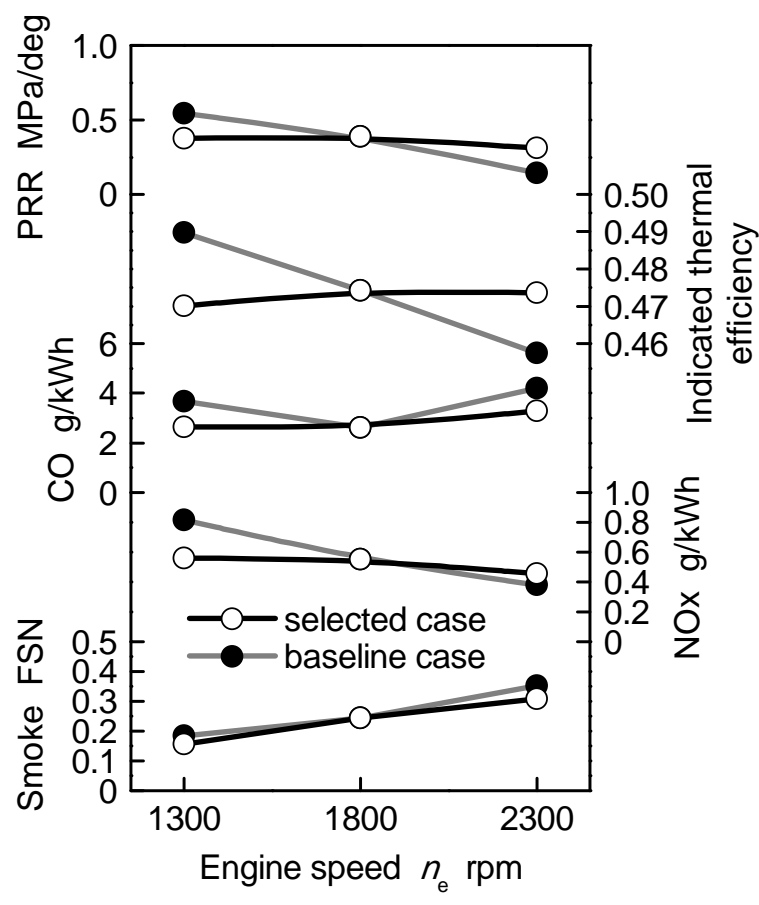

Figure 23 Performance and emissions under selected conditions for various engine speeds.

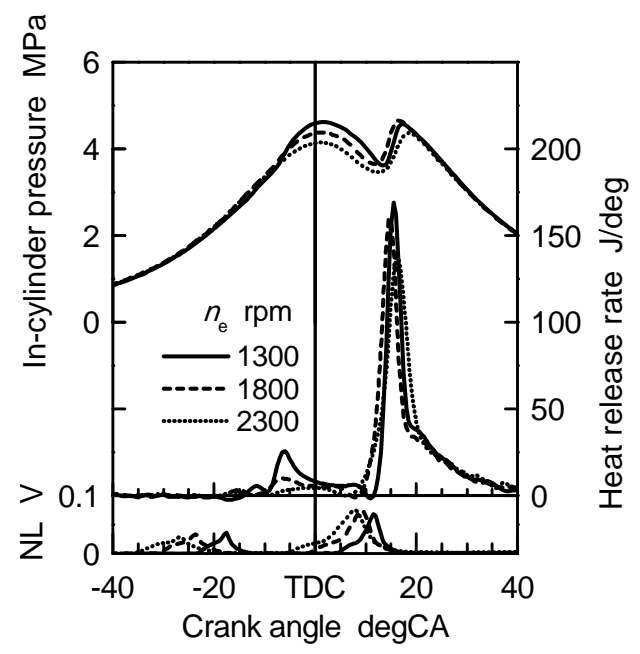

Figure 24 Heat release rate and in-cylinder pressure under selected conditions for various engine speeds.

baseline conditions and Figure 24 indicates the in-cylinder pressure and heat release rate under the selected conditions. The quantity of the first injection is reduced and the first- and second-injection timings are advanced as the engine speed increases. Thus, by selecting the condition, the heat release rates by the second injection almost coincide with each other, as shown in Fig. 23. As a result, the thermal efficiencies and maximum pressure rise rates are

Table 4 Selected conditions at various engine speeds

\begin{tabular}{|c|c|c|c|c|}
\hline $\begin{array}{c}\text { Engine speed } \\
\text { rpm }\end{array}$ & Inj. quantity ratio & $\begin{array}{c}\text { First-inj. timing } \\
\text { degATDC }\end{array}$ & $\begin{array}{c}\text { Second-inj. timing } \\
\text { degATDC }\end{array}$ & $\begin{array}{c}\text { EGR rate } \\
\%\end{array}$ \\
\hline \hline 1300 & $7 / 23$ & -20 & 7.5 & 25 \\
\hline 1800 & $5 / 25$ & -25 & 5 & 25 \\
\hline 2300 & $3 / 27$ & -30 & 0 & 25 \\
\hline
\end{tabular}


comparable. However, the advance of the first-injection timing according to engine speed tends to increase unburned species emissions; therefore, the feasibility of this strategy is influenced by limiting the unburned species emissions.

\section{CONCLUSIONS}

To determine the injection strategies for improving emissions, the thermal efficiency and the maximum pressure rise rate for various engine speeds in PCCl-based diesel combustion with two-stage injection, experiments are performed using a single-cylinder direct-injection diesel engine with varied injection timings, injection-quantity ratios and EGR rates at low and high engine speeds. From the results, the following conclusions are derived.

- In the case of single-stage injection, smoke emission increases as engine speed increases and the maximum pressure rise rate increases as engine speed decreases at a middle load. The change in engine speed influences performance and emissions through the change in ignition delay and, therefore, the change in combustion phasing.

- When the baseline injection condition of two-stage injection is applied to low and high engine speeds, the high maximum pressure rise rate at low engine speed and the low thermal efficiency at high engine speed become problems.

- At low engine speed, retarding of the first- and second-injection timings and increasing the first-injection quantity compared with the base injection condition effectively make the second combustion milder and reduces the maximum pressure rise rate.

- At high engine speed, reduction of the first-injection quantity and advance of the first-injection timing are effective for low smoke and $\mathrm{CO}$ emissions. The advance of the second injection effectively improves thermal efficiency. However, the excessive advance increases NOx and the maximum pressure rise rate.

- For low emissions and high thermal efficiency, the first-injection quantity should be reduced and both of the first- and second-injection timings should be advanced according to the increase in engine speed.

\section{ACKNOWLEDGMENTS}

The authors would like to thank Toyota Motor Corporation for providing the fuel injection system.

\section{REFERENCES}

1. Akihama, K., Takatori, Y., Inagaki, K., Sasaki, S., and Dean, A. M., "Mechanism of Smokeless Rich Diesel Combustion by Reducing Temperature," SAE Technical Paper 2001-01-0655, 2001.

2. Kanda, T., Hakozaki, T., Uchimoto, T., Hatano, J., Kitayama, N., and Sono, H., "PCCl Operation with
Early Injection of Conventional Diesel Fuel," SAE 2005 Trans. J. Engines.: 584-593, 2006.

3. Kimura, S., Aoki, O., Ogawa, H., Muranaka, S. and Enomoto, Y., "New Combustion Concept for Ultra-Clean and High-Efficiency Small DI Diesel Engines," SAE Technical Paper 1999-01-3681, 1999.

4. Helmantel, A., Gustavsson, J., and Denbratt, I., "Operation of a DI Diesel Engine with Variable Effective Compression Ratio in $\mathrm{HCCl}$ and Conventional Diesel Mode," SAE 2005 Trans. J. Engines.: 405-418, 2006.

5. Kitabatake, R., Shimazaki, N., and Nishimura, T., "Expansion of Premixed Compression Ignition Combustion Region by Supercharging Operation and Lower Compression Ratio Piston," SAE Technical Paper 2007-01-3614, 2007.

6. Kanda, T., Hakozaki, T., Uchimoto, T., Hatano, J., Kitayama, N., and Sono, H., "PCCl Operation with Fuel Injection Timing Set Close to TDC," SAE Technical Paper 2006-01-0920, 2006.

7. Opat, R. M., Ra, Y., Gonzalez D., M. A., Krieger, R., Reitz, R. D., Foster, D., and Durrett, R. P., Siewert, R. M., "Investigation of Mixing and Temperature Effects on $\mathrm{HC} / \mathrm{CO}$ Emissions for Highly Dilute Low Temperature Combustion in a Light Duty Diesel Engine," SAE Technical Paper 2007-01-0193, 2007.

8. Horibe, N., Takahashi, K., Kee, S.S., Ishiyama, T., and Shioji, M., "The Effects of Injection Conditions and Combustion Chamber Geometry on Performance and Emissions of DI-PCCl Operation in a Diesel Engine," SAE 2007 Trans. J. Fuels and Lubricants: 387-395, 2008.

9. Helmantel, A., "Reduction of NOx Emissions from a Light Duty DI Diesel Engine in Medium Load Conditions with High EGR Rates," SAE Technical Paper 2008-01-0643, 2008.

10. Eastwood, P., Hardalupas, Y., Morris, T., Taylor, A., Tufail, K., and Winstanley, T., "The Effect of Multiple Fuel-Injections on Emissions of NOx and Smoke with Partially-Premixed Diesel Combustion in a Common-Rail Diesel Engine," IMechE Int. Combustion Engines: Performance, Fuel Economy and Emissions: 285-301, 2007.

11. Hardy, W. L., and Reitz, R. D., "An Experimental Investigation of Partially Premixed Combustion Strategies Using Multiple Injections in a Heavy-Duty Diesel Engine," SAE Technical Paper 2006-01-0917, 2006.

12. Sun, R., and Reitz, R. D., "Modeling Diesel Engine NOx and Soot Reduction with Optimized Two-Stage Combustion," SAE Technical Paper 2006-01-0027, 2006.

13. Weiskirch, C., and Mueller, E., "Advances in Diesel Engine Combustion: Split Combustion," SAE Technical Paper 2007-01-0178, 2007.

14. Koci, C. P., Ra, Y., Andrie, M., Krieger, R., Foster, D., Siewert, R. M., and Durrett, R., "Multiple Event Fuel Injection Investigations in a Highly-Dilute Diesel Low Temperature Combustion Regime," SAE Int. J. Engines 2(1): 837-857, 2009. 
15. Kokjohn, S. L., Swor, T. A., Andrie, M. J., and Reitz, R. D., "Experiments and Modeling of Adaptive Injection Strategies (AIS) in Low Emissions Diesel Engines," SAE Int. J. Engines 2(1): 16-32, 2009.

16. Horibe, N., and Ishiyama, T., "Relations among $\mathrm{NOx}$, Pressure Rise Rate, $\mathrm{HC}$ and $\mathrm{CO}$ in LTC Operation of a Diesel Engine," SAE Technical Paper 2009-01-1443, 2009.

17. Anselmi, P., Kashdan, J., Bression, G., Ferrero-Lesur, E., Thirouard, B., and Walter, B., "Improving Emissions, Noise and Fuel Economy Trade-Off by using Multiple Injection Strategies in Diesel Low Temperature Combustion (LTC) Mode," SAE Technical Paper 2010-01-2162, 2010.

\section{CONTACT INFORMATION}

Naoto HORIBE, Assistant Professor

Tel\&Fax: +81-75-753-5269

Email: horibe@energy.kyoto-u.ac.jp

URL: http://cpel.energy.kyoto-u.ac.jp/

\section{DEFINITIONSIABBREVIATIONS}

EGR Exhaust gas recirculation

ATDC After top dead center

CA Crank angle

CO Carbon monoxide

HC Hydrocarbon
HRR Heat release rate

IMEP Indicated mean effective pressure

NL Output of needle-lift sensor

NOx Nitrogen oxides

$\mathrm{PCCl}$ Premixed charge compression ignition

PM Particulate matter

PRR Maximum pressure rise rate

TDC Top dead center

THC Total hydrocarbon

$\mathrm{d} Q / \mathrm{d} t_{\max }, \mathrm{d} Q / \mathrm{d} \theta_{\max } \quad$ Maximum heat release rate

$n_{\mathrm{e}} \quad$ Engine speed

$q_{1} / q_{2} \quad$ Injection quantity ratio

$q_{\mathrm{f}} \quad$ Injection quantity per cycle

$r_{\mathrm{EGR}} \quad \mathrm{EGR}$ rate

$r_{\mathrm{SW}} \quad$ Swirl ratio

$\theta_{1} \quad$ First-injection timing

$\theta_{2} \quad$ Second-injection timing

$\tau_{\mathrm{ms}}, \tau_{\mathrm{CA}}$ Ignition delay 